much constitutional difficulty in the substitution of an appraisal for the upset price as the measure for the payment of dissenters, particularly where convenience and the equities of the situation, as found by a judge, dictate such a result, and where support for the plan, though not two-thirds support, is bound to be "substantial".

\title{
AGRICULTURAL ADJUSTMENT AND MARKETING CONTROL
}

PUBLIC CONCERN with the efforts of the federal government to alleviate a recurring farm problem by measures aimed at production control and soil conservation $^{1}$ has tended to obscure the disorganized condition of agricultural marketing and the attempt to solve that problem by action under the marketing control provisions of the Agricultural Adjustment Act. ${ }^{2}$ The marketing problem has been more acute in the case of such commodities as milk, fruits, and other perishables than in that of basic commodities like cotton, wheat, and corn. ${ }^{3}$ The difficulty of carrying over perishable and semiperishable products makes it imperative to sell them immediately upon arrival at distribution points; and the heavy selling pressure thus built up at the season's peak frequently has a depressing influence on retail prices which is reflected in lower prices to the producer. Likewise, well-organized central markets such as exist for basic commodities are largely lacking, with the result that producers are compelled to deal with small wholesalers or commission houses whose independent efforts may cause glutted markets in certain localities at a time when others are relatively under-supplied. Furthermore, there are no futures exchanges similar to those for staple products which make continuous price quotations easily available to the producer and permit the shifting of risk through hedging operations by cooperative associations. $^{4}$

1.' See generally Black, Agriculturat Reforat in the United States (1929); Ezekiel and Bean, Ecosomic Bases for the Agricultural adjustarent Act (U.S. Dep't Agric. 1933) : 1 Recent Social Trends (1933) 497: Royal Institute of International Affairs, World Agricllture, Ax International Survey (1932); Jennings and Sullivan, Legal Planning for Agriculturc (1933) 42 YALE L. J. 878; Kern, Fcdcral Farm Legislation: A Factual Appraisal (1933) 33 Cot. L. Rev. 984; Legis. (1936) 84 U. of PA. L. Rev. 878.

2. 48 Sт八т. 31 (1933), as amended by 49 Stat. 750, 7 U.S. C. A. $\$ \$ 601-24$ (Supp. 1935).

3. See Black, op. cit. supra note 1, c.xviii; Hearings bcfore Committce on Agriculture on H.R. 5585, 74th Cong., 1st Sess. (1935) 103.

4. See Hearings before Committec on Agriculture and Forestry on H.R. 3835 , 73d Cong., 1st Sess. (1933) 92 ot seq.; Hearings before Committec on Agriculture and Forestry on S. Res. 37t, 71st Cong., 3d Sess. (1931). For a description of the marketing situation after the war, see Report of the Federal Trade Commission on the Wholesale Marketing of Food (1920) 76 ct scg. In its report the Federal Trade Commission recommended the establishment under iederal control or through federal funds of central food markets and terminals, storage warehouses, refrigerator lines, and other marketing devices. Although these recommendations have failed to become law, 
The relative seriousness of the marketing problem in the field of non-basic commodities, together with the fact that the difficulties of surplus production were less pressing there than in the case of basic commodities, may have suggested the use of different control techniques to those who were attempting to devise a comprehensive plan for agricultural relief. Whatever the reasons, ${ }^{5}$ Congress limited the production control and processing tax features of the Adjustment Act to basic commodities, and devised a scheme for the control of marketing, which, although worded so as to be applicable to all forms of agriculture, has thus far been applied principally only to not-basic products. ${ }^{\circ}$ Under this scheme, the quantity of produce which could be marketed was to be limited by voluntary agreement to be enforced against all shippers, including those not party to the agreement, by a system of licensing under the order of the Secretary of Agriculture. ${ }^{7}$ Furthermore, prices and trade practices were to be regulated by agreement with a view to stabilizing markets. ${ }^{8}$ It should be noted, however, that although this plan emphasized the control of marketing, it made possible an indirect control of production to the extent that the restriction of marketing would influence producers to decrease their output.

the proposal that wholesale dealers be required to secure federal licenses, that unfair conduct in the interstate marketing of food be prohibited, and that federal inspection and standards be provided, has been adopted in the Perisnadle Agriculturar Co:sModrties ACr, 46 Stat. 531 (1930), as amended by 48 Stat. 584 (1934), 7 U.S.C.A. $\$ 499$ (Supp. 1935), as amended by Pub. L No. 702, 74th Cong., 2d. Sess. (June 19, 1936). The validity of the statute was assumed in Spano v. Western Fruit Grovers, 83 F. (2d) 150 (C. C. A. 10th, 1936), and Barker-Mriller Distributing Co. v. Berman, S F. Supp. 60 (W. D. N. Y. 1934) ; cf. Hartford Accident \& Indemnity Co. v. Illinois ex rel. McLaughlin, 298 U.S. 154 (1936); Krueger v. Acme Fruit Co., 75 F. (2d) 67 (C. C. A. 5th, 1935).

5. Practical considerations as to effective administration may also have influenced Congress to employ different methods. Thus, it may have been thought that the shippers of basic commodities were too widely scattered and disorganized to make marketing agreements effective. And the crop ct -tailment plan may not have bren applied to non-basic commodities because many of them are sold without processing. and thcrefore afford no basis for a processing tax. See Achiceing a Balanced Agriculture (Agric. Adjust. Admin. 1934) 26.

6. Section 11, 48 Star. 38 (1933) as amended by 48 Stat. 528 (1934), 48 Stat. 670 (1934), 49 Stat. 782, 7 U.S.C.A. $\$ 611$ (Supp. 1935), defined the basic commodities as wheat, rye, flax, barley, cotton, feld corn, grain sorghums, hogs, cattle, rice, potatoes, tobacco, peanuts, sugar beets and sugarcane, and milk and its products. Under the control plan the acreage or production ior market of these commodities was to be reduced a flat percentage through voluntary agreements with producers in return for rental or benefit payments financed by processing taxes. See Report of the Committee on Agriculture on $H . R .3 \$ 3573 \mathrm{~d}$ Cong., 1st Sess. (1933) 3 . While under the original Act marketing agreements were made for wheat, tobacco, peanuts, and rice for the purpose of facilitating exports or carrying over during the 1933 emergency, most of the agreements covered milk and similar perishable products. NounSE, MIARKETING AGREEASENTS UNDER THE A. A. A. (1935) 64 et seq.

7. Section $8(3), 48$ Stat. 35 (1933).

8. Section $8(2), 48$ Stat. 34 (1933). The first expression of the marketing agreement idea was in the McNary-Haugen Bills. See Hearings before the Commillee on 
The Supreme Court decision in United States $v$. Butler, invalidating the production control and processing tax sections of the Adjustment Act, has raised a perplexing question as to the status of the marketing control sections. Nevertheless, the government is looking to them, as an organic part of its farm program, to provide a framework within which effective cooperation among competing producers can be secured, and with it a potential realization of market economies, and a control of trade practices, which it considers a step toward orderly agricultural marketing.

The details of the marketing sections of the Act, as amended in 1935 , $^{10}$ may be summarized as follows. Sections $8 b$ and $8 c$ empower the Secretary of Agriculture to issue orders and make marketing agreements with producers and handlers of agricultural commodities in the current of interstate commerce. ${ }^{11}$ These orders and agreements are intended to effectuate a comprehensive regulation of.several phases of the marketing process. Thus, they are to limit total shipments to markets during a season or shorter period, prorating the quota for the industry among individual shippers on the basis

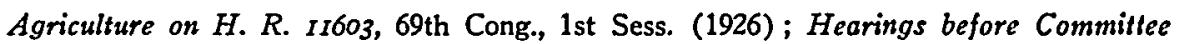
on Agriculture and Forestry on S. 4808, 69th Cong., 2d Sess. (1927).

9. 297 U. S. 1 (1936), (1936) 49 HaRv. L. Rev. 828. See Grant, Commerce Production and the Fiscal Powers of Congress (1936) 45 YALE L. J. 751, 991.

10. 49 Stat. 753, 7 U.S.C.A. $\$ \$ 608 b, 608 c$ (Supp. 1935). Before the decision in Schechter Poultry Corp. v. United States, 295 U. S. 495 (1935), invalidating the codes under the National Industrial Recovery Act, a number of lower courts had refused to enforce licenses issued by the Secretary of Agriculture under the original marketing control provisions of the Adjustment Act. Berdie v. Kurtz, 75 F. (2d) 898 (C. C. A. 9th, 1935) ; Darger v. Hill, 76 F. (2d) 198 (C. C. A. 9th, 1935) ; Edgewater Dairy Co. v. Wallace, 7 F. Supp. 121 (N.D. Ill. 1934); Columbus Milk Producers' Co-op Ass'n v. Wallace, 8 F. Supp. 1014 (N.D. Ill. 1934); United States v. Neuendorf, 8 F. Supp. 403 (S. D. Iowa 1934); United States v. Greenwood Dairy Farms, 8 F. Supp. 398 (S. D. Ind. 1934); Douglas v. Wallace, 8 F. Supp. 379 (W. D. Okla. 1934); Royal Farms Dairy v. Wallace, 8 F. Supp. 975 (D. Md. 1934); Wallace v. Smith, 11 F. Supp. 782 (S. D. Tex. 1935); Allen v. Wallace, 12 F. Supp. 515 (N. D. Okla. 1935). The Secretary was sustained in only two cases: United States v. Calistan Packers, 4 F. Supp. 660 (N. D. Cal. 1933); United States v. Shissler, 7 F. Supp. 123 (N.D. Ill. 1934). When the decision in the Schechter case indicated that the marketing provisions were too broad in including transactions "in any way affecting" interstate commerce, the House Committee on Agriculture proposed amendments to the Adjustment Act substituting orders for licenses, setting forth the nature of the orders in detail, and restricting their scope to transactions "in the current of interstate or foreign commerce, or which directly burden, obstruct, or affect" such commerce. See 79 Cong. Rec. 9457 (1935). These amendments were adopted. 49 Stat. 753, 7 U. S. C. A. $\$ \S 608$ b, 608c (Supp. 1935).

11. Under $\S 8 \mathrm{c}$ of the amended Act orders may be issued only for a limited number of commodities and their prolucts: milk, fruits (not including apples, or fruits for cenning, other than olives), tobacco, vegetables (not including vegetables for canning, other than asparagus), soybeans and naval stores. Milk and tobacco were basic comr.odities within the crop control and processing tax provisions of the original Act. 48 Stat. 38 (1933), 7 U.S.C. $\$ 611$ (1934). 
of each shipper's current or past business.12 In addition to direct proration, rather high standards of quality are to be employed whenever necessary to exclude low-grade products. ${ }^{13}$ Likewise, orders may compel shippers to sell only at prices filed in accordance with the terms of the order. ${ }^{14}$ Whatever cannot be shipped, either because of low quality or because of production in

12. Sections $8 c(6)(A)-8 c(6)(C)$. Under the order regulating Californin and Arizonz oranges and grapefruit, each shipper must report to the Growers Advisory Committee the amount of fruit which he controls under authority to ship or to which he has legal title or for which he has paid 5\% of the purchase price. Order Regulating the Houtling of Oranges and Grapefruit (Agric. Adjust. Admin. 1936)9. The shipper's individual prorate base is then computed by the Committee as the ratio of the amount of fruit controlled by the shipper to the total amount of fruit grown in California and Arizona. According to this prorate base, the shipper is allotted a share of the total weekly shipments which the Distribution Committee deems advisable in view of market conditions. Id. at 10,11. Shippers may exchange allntments, or may exceed them by a percentage of tolerance, but in no case may the shipments for the entire season exceed the total of the allotments. Id. at 12. Terms similar to these are found in orders regulating California pears, plums, and peaches; Colorado peas and caulifower; Florida citrus fruit; and Washington lettuce, peas, and cauliflower. The orders regulating walnuts and Southeastern watermelons, on the other hand, provide only for seasonal limitations. Marketing agreements and orders for milk and its products may not contain any limitations on the marketing of such products. Section $8 c(6)(G)$. On the purpose of periodic limitation of shipments, see Braurs, The Citrus Procrazs (Agric. Adjust. Admin. 1934) ; Braun and Gold, Prices and Ixcosre in tme Naval Stores I:idusmy (Agric. Adjust. Admin. 1934); Gold, The Marketrng of Watersarelo:s (Agric. Adjust. Admin 1936); Weilssan, Regulating Shipusents of Califorsina Orasiges (Univ. of Calif. 1936). The theory underlying periodic limitations is that a larger quantity of fruits and vegetables can be moved at a higher average price to growers in a stabilized market than in a demoralized one. See Taussig, Is Market Price Determinate? (1921) 35 QUAR. J. Ecos. 394. This amounts merely to saying that in an efficient market more goes to producers and less to middlemen than in an inefficient market; the quantum of profit decreases as the factor of risk is reduced. Cosssors, InstrTutronal. EcoNomics (1934) 555.

13. Section $8 c(6)(A)$. Regulation of grade, size, or quality is provided for in all the general crop orders except that for California oranges and grapefruit. It is argued in NourSE, op. cit. supra note 6, at 322 et seq., that this method of increasing returns by preventing the competition of inferior grades is more complieated than it scems. In the milk orders grades are based on butterfat content and on the use to which the milk is put by the distributor; milk for fluid purposes receives the highest rate. See, for example, Order Regulating the Handling of Milk in The Greater Boston Marketing Area (Agric. Adjust. Admin. 1936) 6, 7; Order Regulating the Handling of Ifill in the St. Louis Marketing Area (Agric. Adjust. Admin. 1936) 5-7.

14. Section $8 c(7)$ provides that each order shall contain one or more terms prohibiting unfair methods of competition and unfair trade practices in the handling of the commodity, providing (except for fluid milk and cream) for the sale of the commodity only at prices filed by the handler, and providing for the selection by the Secretary of agencies to administer the order, make rules and regulations, investigate violations, and recommend amendments to the order. The Secretary has not yet required the filing of prices under any order. The St. Louis milk order is the only one regulating unfair practices: "Each handler shall refrain from acts which constitute unfair methods of competition by way of indulging in any practices with respect to the 
excess of quota, is to be placed in a reserve pool ${ }^{15}$ from which amounts may be withdrawn if current harvests fail to provide sufficient quantities for market needs; the remainder may be distributed to relief agencies, exported, or converted into by-products. The agreements become effective upon issuance of an order by the Secretary. While an agreement may be the basis of such an order only if signed by handlers of $50 \%$ of the volume of the product, an order may issue without an agreement if the Secretary finds that the shippers' failure to sign an agreement would obstruct the policy of the Act. Approval of the orders by producers is in some degree assured by the provision requiring the Secretary to determine that the issuance of the order is favored by two-thirds of the producers or producers of twothirds of the volume of the commodity. ${ }^{16}$ Failure to obey the Secretary's order is punishable by a heavy fine for each day's violation, ${ }^{17}$ and the federal courts are given jurisdiction to impose such fines ${ }^{18}$ and to entertain proceedings by the Secretary to enjoin the violation of the Act or of orders issued under it. ${ }^{19}$ Further penalties may be levied upon any person willfully exceeding any allotment or knowingly aiding or participating in such act by means of a forfeiture equal to three times the market value of the excess. ${ }^{20}$ In many cases, however, the usual administrative procedure of allowing the violator a hearing on an order to show cause why proceedings should not be instituted may secure compliance without resort to the courts. ${ }^{21}$

transportation of milk for, and the supplying of goods or services to, producers from whom milk is purchased, which tend to defeat the purpose and intent of this order." Order Regulating the Handling of Milk in St. Louis Marketing Area (Agric. Adjust. Admin. 1936) 9, 10.

15. Section $8 c(6)(E)$. A surplus pool is provided only in the walnut order. Order Regulating the Handling of Western Walnuts (Agric. Adjust. Admin. 1935) 9-14. Compare the method employed under the Agricultural Marketrng Act, 46 Stat. 11 (1929), 12 U.S.C. $\$ \$ 1141-1141$ j (1934).

16. Sections $8 c(8)$ and $8 c(9)$. Compare $\$ 3(a)$ of the Natronal Industrial RecoverY Acr, 48 Srat. 196 (1933), 15 U. S. C. $\$ 703$ (a) (1934). Presumably the Secretary may determine whether the specified percentage of producers approves the proposed order at the hearing provided under $\S \S 8 \mathrm{c}(8)$ and $8 \mathrm{c}(9)$.

17. Section $8 c(14)$. No penalty is imposed between the date of the petition and the date of the Secretary's ruling upon a handler who files a petition in good faith under $\S 8 \mathrm{c}(15)$.

18. Section 9 of the Judictary Act, 1 Stat. 76 (1789), 28 U. S. C. $\S 41(9)$ (1934).

19. Jones-Costigan Act, 48 Stat. 675 (1934), 7 U. S. C. $\$ 608$ a (6) (1934).

20. Jones-Costigan ACt, 48 Stat. 674 (1934), 7 U. S. C. $\$ 608 a(5)$ (1934).

21. General Regulations (Agric. Adjust. Admin. 1933) Series 3. Of the 653 complaints made between August 1, 1933, and June 1, 1935, 330 were adjusted without proceedings; "show cause" orders were issued in 323 cases; 59 cases were adjusted before hearing; and in 53 cases ground was found for court action. Nourse, op. cil. supra note 6 , at 271-272. For the purposes of enforcing the marketing agreements or orders under the amended Act, the Secretary is empowered to require reports from handlers and signers of agreements, and to examine books and other records. Section $8 \mathrm{~d}(1)$. Compare Comment, Investigatory Powers of the Securities and Exchange Commission (1936) 44 Y ALE L. J. 819. 
The procedure in issuing orders or agreements and in carrying out their provisions consists essentially of monopolistic self-regulation by a group of competitors supervised by the Secretary; proposed orders, drafted in most cases by the producing or shipping groups, are discussed at formal hearings conducted by representatives of the Secretary to ascertain the need for regulation; ${ }^{22}$ but there is no representation for consumer interests, as such, and no effective pressure against monopolistic action by producers. ${ }^{2 a_{3}}$ In general the orders provide for one or more committees or control boards selected by the Secretary on nomination of growers and handlers. ${ }^{23}$ These committees perform the field work in administering orders and agreements and in making the rules and regulations covering the operations of the control plans. Their action, however, is not final in most proceedings. The approval of the Secretary is necessary for the fixing of prorate bases and allotments and the amendment of orders; ${ }^{24}$ and handlers who desire to be exempt from an order or who claim that any provision is not imposed in accordance with the law may petition the Secretary for a hearing on their grievance, subject to a court review of the Secretary's ruling on the petition. ${ }^{25}$

The experience of the government in this adventure in public control is probably too short to allow evaluation of its.results. Of the orders thus far issued under section 8c, the seven applying to general crops, such as citrus fruits, walnuts, and watermelons, have been uniformly characterized by a system of quotas, while the five applying to milk have principally

22. Sections $8 c(3)$ and $8 c(4)$; General Regulations (Agric. Adjust. Admin. 1936) Series A; Ibid. (1936) Series B. The evidence introduced at the hearing provides the foundation for findings called for by $\S \mathrm{Sc}(4)$. To the effect that due process requires such findings of fact in administrative orders, see Panama Refining Co. v. Ryan, 293 U. S. 388, 431 (1935) ; cf. Pacific States Box Co. v. White, 296 U. S. 176, 186 (1935) (administrative order upheld despite lack of findings). Although under the original Act $[\$ \delta(3)]$ due notice and opportunity for hearing was given before a license was revoked, licenses could be imposed without granting a hearing. The provisions of the amended Act dispel doubts as to the validity of this procedure by clearly meeting requirements of notice and hearing. See generally Comment (1934) 34 CoL L REv. 332.

22a. Contrast $\$ 3(b)$ of the Brtuarnous Coal Cosservation Act, 49 Stat. 992, 15 U.S.C.A. $\$ 803$ (b) (Supp. 1935), which provides for a Consumers' Counsel to represent the consuming public in proceedings before the National Bituminous Coal Commission [\$3(a)] by offering evidence and argument, examining witnesses, requesting the issuance of a subpoena or other process, conducting investigations, or requesting the Commission to furnish information or conduct investigations.

23. For example, under the walnut order the Control Board of nine members includes eight selected from a panel of 32 nominated half by growers and half by distributors; the ninth member is selected from nominees of the Control Board. Order Regulating the Handling of Western Walnuts (Agric Adjust. Admin 1935) 5, 6.

24. Sections $8 c(6)(B)$ and $8 c(6)(C)$. Under $\S \& c(16)(A)$, the Secretary may terminate any order or provision of an order which he finds obstructs or does not effectuate the policy of the Act.

25. Section 15. 
employed direct price-fixing. The intention of the milk orders, as in most state milk control plans, is to set the price of milk according to classes based on the use to which it is put. ${ }^{26}$ The system prevents surpluses by furnishing the producer with powerful economic incentives to produce no more than the quantity and quality of milk that can be handled advantageously, since whatever milk cannot be sold at the relatively high fluid milk price is paid for at the lower cream or by-product prices. ${ }^{27}$ In the case of general crops, however, instead of naming a minimum price and abiding by the decision of the market as to what volume of products will be absorbed at that level, the orders have attempted to limit shipments to a point below the normal volume in order to bring about a desirable price level by a restriction of supply. ${ }^{28}$ In addition, it is hoped that the system of proration over short periods will induce growers to plan a staggered harvesting program whereby the flow of products to market and the movement of wholesale prices will be steadied. ${ }^{29}$

It is not surprising that the attempt on a large scale to introduce governmental sanctions into the field of agricultural cooperation should meet with determined opposition and present delicate problems of enforcement. In two cases it has been necessary for the government to institute legal proceedings. In one, ${ }^{30}$ the United States district attorney sought an injunction restraining the defendant from engaging in interstate commerce unless he applied for allotments under the order regulating California oranges and grapefruits. The district court issued an injunction, holding that section $8 \mathrm{c}$, under which the order was issued, was separable from the sections invalidated in United States $v$. Butler; ${ }^{31}$ that there were sufficient standards setting reasonable limitations on the discretion of the Secretary of Agriculture ;2 and that section $8 \mathrm{c}$ constituted a valid regulation of interstate com-

26. Section $8 c(5)(A)$. Although $\S 8 c(5)$ (B) provides the alternative of a uniform method of payment, the use classification has been generally employed. See BLACK, The Dairy Industry and the A. A. A. (1935) 152.

27. Black, op. cit. supra note 26 , at 269.

28. In the walnut order the "salable percentage" is fixed at 70 . Order Regulating the Handling of Western Walnuts (Agric. Adjust. Admin. 1935)8.

29. A consideration of recent figures indicates that the California citrus order may have secured some degree of stability in the industry. From April, 1934, to November, 1935, the index numbers of the price of California oranges fluctuated between 45.5 and 70.7. During the first five months of proration, starting in February, 1936, the index numbers moved between 55.8 and 56.6. Wholesale Prices (U. S. Bureau of Labor Statistics, 1934-1936) Monthly Builetins.

30. United States v. Edwards, 14 F. Supp. 384 (S. D. Cal. 1936). A permanent injunction has been issued, with opinion. United States v. Edwards, Dist. Ct., S.D. Cal. Sept. 8, 1936.

31. 297 U.S. 1 (1936).

32. The question of delegation of powers has been sufficiently covered elsewhere. See Cousens, The Delegation of Federal Legislative Power to Executive Officials (1935) 33 Micr. L. Rev. 512; Comment (1935) 48 Harv. L. Rev. 798. The detailed specifi- 
merce which was unobjectionable on grounds of due process. In the other, ${ }^{33}$ on an application for a mandatory injunction to compel twenty-eight defendants to comply with the order regulating the handling of milk in the Greater Boston area, the court granted a motion to dismiss on the grounds that the marketing provisions were designed to regulate production rather than commerce, and that they were inseparable from the processing tax and production control provisions voided in the Butler case, and therefore invalid.

In view of recent decisions, the issue of separability may have an important bearing on the ultimate fate of the marketing provisions of the Adjustment Act. The conventional formula for determining whether a provision is separable from invalid portions of a statute specifies two tests. First, it is said that the provision in question must be capable of being practically administered alone $;^{34}$ and second it must be found that the legislature would have enacted the statute stripped of its invalid portions, ${ }^{35}$ despite a presumption that the legislature intended the act to be effective in its entirety..$^{30}$ It seems clear that the marketing provisions satisfy the first requirement, for they have been separately administered with no more than the usual practical difficulties ever since the effective date of the Adjustment Act, and continue to be so administered although the remainder of the Act has been rendered . inoperative. But their separability is more doubtful when tested by the second requirement. A finding as to what Congress would have done had certain provisions been removed from the Act before its passage must inevitably be based largely on speculation. Perhaps the best evidence on this question is the fact that the statute contains the now familiar separability clause, ${ }^{37}$ providing

cations found in $\S 8 \mathrm{c}$ indicate that the provisions are not subject to challenge on the ground of indefiniteness as to the content of the orders. Section $8 \mathrm{~b}$ requires merely that marketing agreements effectuate the policy of the Act; but the question of delegation of power may not arise, since the agreements are wholly voluntary. See Schechter Poultry Corp. v. United States, 295 U. S. 495, 529 (1935).

33. United States v. Buttrick, 15 F. Supp. 655 (D. Mass. 1936).

34. See Dorchy v. Kansas, 264 U.S. 286, 290 (1924); Warren v. Mayor and Aldermen of Charlestown, 2 Gray 84, 99 (Mass. 1854): People ex rcl. Alpha Portland Cement Co. v. Knapp, 230 N.Y. 48, 60, 129 N.E. 202, 207 (1920) ("The principle of division is not a principle of form. It is a principle of function.") ; 1 COOLEX, Cosistitutronal Liantations (8th ed. 1927) 359; Comment (1927) 40 HABv. L. Rev. 626.

35. Allen v. Louisiana, 103 U. S. 80 (1880) ; Butts v. Merchants \& Miners Transportation Co., 230 U.S. 126 (1913).

36. See Field v. Clark, 143 U.S. 649, 695, 696 (1892) (tariff act); Reagan v. Farmers' Loan \& Trust Co., 154 U. S. 362, 395, 396 (1894) (income tax act) ; Connolly v. Union Sewer Pipe Co., 184 U.S. 540, 565 (1902) (anti-trust act) ; Riccio v. Mayor of Hoboken, 69 N. J. Law 649, 662, 55 Atl. 1109, 1113 (1903).

37. A number of recent statutes have included a separability clause. Tre Securmtres ACT, 48 Stat. 88 (1933), 15 U. S.C. $\$ 77 z$ (1934); Securities Excinaige Act, 48 Stat. 905, 15 U.S.C. \$78gg (1934); National IndustrIal Recoveny ACT, 48 Stat. 211 (1933), 15 U.S.C. \$711 (1934); Soctal Security Act, 49 Stat. 648, 42 U. S. C. A. $\$ 1303$ (Supp. 1935); Public Utmity Holdng Couspany Act, 49 Stat. 837, 15 U. S. C. A. $\$ 79 z-6$ (Supp. 1935); Brtuzrmous Cont Consenpatron ACT, 49 
that a judicial determination of the unconstitutionality of any section of the statute is not to affect the validity of the remaining provisions. Such a clause, while not conclusive, should at least be considered a strong indication that Congress would have enacted the marketing provisions alone. ${ }^{38}$ The steady expansion and simplification of judicial power is reflected in the ease with which the Supreme Court ignores these clauses. For example, despite the inclusion of a separability clause, it was held in Carter v. Carter Coal Company $y^{30}$ that the price regulations of the Guffey Coal Act ${ }^{40}$ were inseparable from the invalid labor provisions, on the ground that Congress would not have enacted the price regulations alone. The Court justified its conclusion by reasoning that without the labor provisions, the Act would not accomplish its principal objective of a balanced control of the coal industry. It can be argued that this reasoning, however valid it may be in the Carter case, is not pertinent in the case of the marketing provisions, which, instead of forming one of two parts of a single regulatory system designed to balance each other, constitute one of two schemes intended to solve different problems by different methods, one regulating directly the production of basic commodities, and the other regulating the marketing of non-basic commodities. ${ }^{41}$ But such arguments are of doubtful value in predicting the ultimate disposition of the marketing sections; the vagueness of the second requirement of separability, demanding judicial clairvoyance as to what Congress would have done had things been otherwise than they were, appears to leave the final answer largely to the sympathies of the Supreme Court.

The traditional theories of congressional power over interstate commerce provide formulae broad enough to sustain the provisions of the marketing orders limiting the quantities and fixing the prices of commodities moving across state lines. ${ }^{42}$ Sales made in interstate transactions, whether preceding or following shipment across state lines, appear to constitute interstate commerce itself within all the definitions thus far suggested by the Supreme

Stat. 1007, 15 U. S. C. A. $\$ 819$ (Supp. 1935); National Labor Relations. Act, 49 StAT. 457,29 U. S. C. A. $\$ 165$ (Supp. 1935).

38. It is said that a separability clause reverses the presumption that the legislature intended the act to be effective in its entirety. See Crowell v. Benson, 285 U. S. 22, 63 (1932) (longshoremen's compensation act); Utah Power \& Light Co. v. Pfost, 286 U. S. 165, 184 (1932) (license tax act); Champlin Refining Co. v. Corporation Comm., 286 U.S. 210, 234, 235 (1932) (oil production allotment act); cf. Williams v. Standard Oil Co., 278 U.S. 235, 242-44 (1929) (gasoline price-fixing act; provisions regulating unfair practices held inseparable).

39. 56 Sup. Ct. 855 (1936).

40. 49 Stat. 991, 15 U. S. C. A. $\$ \$ 801-827$ (Supp. 1935). See Comment (1935) 45 YALE L. J. 293.

41. See discussion in Hearings before Committee on Agriculture on H. R. 5585, 74th Cong., 1st Sess. (1935) passim.

42. Cf. Gibbons v. Ogden, 9 Wheat. 1 (U.S. 1824); Champion v. Ames, 188 U.S. 321 (1903); Minnesota Rate Cases, 230 U.S. 352 (1913); Ribble, The Current of Commerce (1934) 18 MrNs. L. Rev. 296; Stern, That Commerce Which Concerns More States Than One (1934) 47 Harv. L. Rev. 1335. 
Court. ${ }^{43}$ To regulate the factors of price and quantity in such transactions is therefore to regulate interstate commerce, not merely circumstances antecedent to, or consequent upon interstate commerce.tt The present Supreme Court clearly had this argument in mind when it said in the Schechter case: "But the code provisions, as here applied. do not concern the transportation of the poultry from other States to New York, or the transactions of the commission men or others to whom it is consigned. or the sales made by such consignees to defendant. When . . . the poultry was trucked to their [defendants'] slaughterhouses in Brooklyn for local disposition : . . the interstate transactions . . . ended." 15 But whether or not the marlieting provisions can be sustained as regulations of interstate commerce per se, they seem clearly valid when compared with the regulations which have been upheld on the doctrine that Congress may regulate activities directly affecting such commerce. In the stockyards and grain exchange cases. ${ }^{t 6}$ federal regulation of the praccices and charges of commission men and the conduct of brokers was sustained; and if it be objected that the activities there regulnted occurred at an intermediate point in the flow of interstate conmerce rather than at its source or termination, reliance may be placed upon cases arising under the Sherman and Clayton Acts, ${ }^{47}$ in which the Supreme Court has upheld national regulation of activities whose principal effect was upon the price and quantity of goods moving in interstate commerce, whether those activities occurred in the state of origin or destination. If Congress may restrain price-fixing and monopolistic control of distribution by inlividuals

43. See Dahnke-Walker Milling Co. v. Bondurant. 257 U.S. 282, 290 (1921); Lemke r. Farmers Grain Co., 258 U.S. 50, 59, 60 (1922) : Flanagan v. Federal Coal Co., 267 U.S. 222, 225 (1925); Public Utilities Commission v. Attleboro Steam \& Electric Co., 273 U.S. 83, 90 (1927) : Federal Trade Commission v. Pacific StatiPaper Trade Assin. 273 U.S. 52, 64 (1927); of. Baldwin v. Seelig. 294 U. S. 511 (1935). Cases involving state laws imposing license taxes, occupational tases, or the like furnish ready analogies. Robbins v. Shelby County Taxing District, 120 U.S. 489 (1887) : Bremnan v. Titusville, 153 U.S. 259 (1894) ; Crew Levick Co. v. Pennsylvania, 245 U.S. 292 (1917).

44. See Powell. The Scope of the Commerce Pouter in Essays ix Hosor of Frusw J. Goonxow (1935) 197.

45. Schechter Poultry Corp. v. United States, 295 U. S. 495, 542, $5+3$ (1935).

46. Stafford v. Wallace, 258 U.S. 495 (1922): Board of Trade v. OIsen, 262 U.S.

1 (1923): Tagg Bros. \& Moorhead v. United States, 280 U.S. 420 (1930).

47. Montague \& Co. v. Lowry, 193 U.S. 38 (1904): Northern Securities Co. v. United States, 193 U.S. 197 (1904); Swift \& Co. v. United States, 196 L..S. 375 (1905) ; Standard Oil Co. v. United States, 221 U.S. 1 (1911). The Court has held that the reiusal of union men in one state to handle goods made in a non-union factory in another is an undue restraint of trade. Loewse v. Lawlor, 208 U.S. 274 (1908); Duplex Printing Press Co. v. Deering, 254 U.S. 443 (1921): Bedford Cut Stone Co. v. Journeymen Stone Cutters' Ass'n. 274 U.S. 37 (1927): of. Coronado Coal Co. v. United Jine Workers, 268 U.S. 295 (1925); Local 167, International Brotherhood of Teamsters v. United States, 291 U.S. 293 (1934); Comment (1935) 35 CoL. L. REv. 1072. 
where interstate commerce is concerned, it would seem to follow that, aside from the question of due process, Congress itself may fix prices and control distribution in such commerce.

Perhaps the main attack on the foregoing argument will be based on the contention that here, as in Hammer v. Dagenhart, ${ }^{48}$ the power to regulate interstate commerce is being invoked to support what is in fact a regulation of production beyond the reach of the federal government. The proposition seems to ignore fundamental differences. In Hammer $v$. Dagenhart, the evil sought to be regulated was a part of the productive process with no apparent relation to the movement of goods. But in this case the regulation is designed to solve a serious marketing problem in which the movement of commodities in interstate commerce plays a significant part; it may realistically be contended that any effect the regulation may have upon production is incidental.

If the regulation of interstate transactions is sustained, perplexing problems may arise as to when the varying fraction of product moving in intrastate commerce can be included within the scope of regulatory orders. ${ }^{40}$ Under the doctrine of the Shreveport case, ${ }^{50}$ the federal government may regulate transactions otherwise within the sphere of state control when necessary to render effective the exercise of the interstate commerce power and prevent discrimination against interstate commerce. In the case of milk and other commodities which are produced in a large number of states, it may be argued that a denial of federal control over the marketing of a product within the producing state would allow the intrastate product to undersell competing products coming in from other states whose price would be determined under a marketing order, and that the resulting discrimination would be a burden on interstate commerce and seriously impede the national agricultural program. This argument is weaker, however, in the case of those commodities whose sources of supply are concentrated in a few states, for ther there is likely to be little interstate movement into the producing states in any event. ${ }^{50 a}$

48. 247 U.S. 251 (1918). See Cushman, The National Police Pozver under the Commerce Clause of the Constitution (1919) 3 Mins. L. Rev. 289, 381, 452; Powell, Child Labor, Congress, and the Constitution (1922) 1 N. C. L. REv. 61.

49. In the case of walnuts and oranges, for example, about $90 \%$ of the total production moves across state lines. Order Regulating Handling of Western Walnuts (Agric. Adjust. Admin. 1935) 1: Order Regulatiny Handling of Oranges and Grapefruit (Agric. Adjust. Admin. 1936) 1.

50. Houston, E. \& W. Texas Ry. v. United States, 234 U.S. 342 (1914); cf. Wisconsin R. R. Commission v. Chicago, B. \& A. R. R., 257 U. S. 563 (1922); Florida v. United States, 292 U. S: 1 (1934).

50a. Under the changed wording of the Act [see supra note 10] a court may invalidate an order attempting to regulate intrastate commerce on the ground that the order is nonstatutory rather than that the statute is unconstitutional. Cf. Ward Baking Co. v. Federal Trade Commission, 264 Fed. 330 (C. C. A. 2d, 1920). 
The provisions of the marketing orders most vulnerable to attack on the ground that they constitute restraints upon the liberty of commercial action within the prohibition of the Fifth Amendment are those limiting shipments of general crops and fixing the prices of milk. Admittedly price fixing and limitations on commerce both deprive the entrepreneur of his potential right to obtain by negotiation more or less than the fixed price or to sell more than the fixed quantity. Whether or not the federal government now has the power to impose such restrictions on business activity in interstate commerce remains, of course, a matter for the discretion of the Supreme Court ${ }^{51}$ but the Court's acquiescence in other exercises of federal control over interstate business, including price fixing, leaves the question less open to doubt. ${ }^{52}$

Like any discussion of power rather than policy, this survey of the constitutional issues raised by the agricultural marketing statute should be qualified by an inquiry into the contribution which marketing control can make to a generalized plan for agricultural control. It is plain enough that the

51. For those who seek to forecast through consideration of the cases, the validity of the provisions in issue will depend upon a comparison between their reaconableness and the reasonableness of statutes fixing house rents, Block v. Hirsh, 256 U.S. 135 (1921) ; attorneys' fees, Yeiser v. Dysart, 267 U. S. 540 (1925); coal prices, Highland v. Russell Car \& Snow Plow Co., 279 U.S. 253 (1929); stoclyard agencies' charges, Tagg Bros. \& Moorhead v. United States, 280 U.S. 420 (1930); insurance agents' commissions, O'Gorman \& Young v. Hartford Fire Ins. Co., 282 U.S. 251 (1931); and petroleum quotas, Champlin Refining Co. v. Corporation Commission, 285 U.S. 210 (1932); and the unreasonableness of statutes regulating labor conditions in meat packing houses, Wolff Packing Co. v. Court of Industrial Relations, 262 U.S. 522 (1923); milk price differentials, Fairmount Creamery Co. v. Minnesota, 274 U.S. 1 (1927); theatre ticket brokers' charges, Tyson \& Bro. v. Banton, 273 U. S. 418 (1927); employment agencies' fees, Ribnik v. MicBride, 277 U.S. 350 (1928); gasoline prices, Williams v. Standard Oil Co., 278 U. S. 235 (1929); and entrance into the ice industry, New State Ice Co. v. Liebmann, 285 U.S. 262 (1932).

52. As a result of the decision in Wabash, St Louis \& Pac Ry. v. Illinois, 218 U.S. 557 (1886), federal regulation of railroads has never been seriously challenged. It has been held that Congress may regulate railroad rates, Gulf, Colorado \& S. F. Ry. v. Hefley, 158 U.S. 98 (1895) ; Dayton-Goose Creek Ry. v. United States, 263 U.S. 456 (1924); fix wages and hours of labor on railroads, Wilson v. New, 243 U.S. 332 (1917); provide for arbitration of railway labor disputes, Texas \& New Orleans R. R. v. Brotherhood of Railway \& Steamship Clerks, 281 U. S. 54 S (1930); and regulate the charges of stock-yard agencies, Tagg Bros. \& Mroorhead v. United States, 280 U.S. 420 (1930). But of. Railroad Retirement Board v. Alton R. R., 295 U. S. 330 (1935). Although the cases may be distinguished as relnting to business affected with a public interest [cf. Hamilton, Affectalion with Public Interest (1930) 39 Yale L. J. 1089], it is thought by some that Nebbia v. New York, 291' U.S. 502 (1934) has eliminated the concept of public interest. The rule of the $N$ cbbio case states the principle of due process in a simple, but inclusive form: "Price control, like any other form of regulation, is unconstitutional only if arbitrary, diseriminatory, or demonstrably irrelevant to the policy the legislature is free to adopt. . . "291 U.S. 502, 539 (1934). 
problem of economic planning for agriculture will not be solved even if the statute survives in the courts. While the halting attempts at regulation now under way, affirming legislative recognition of a widespread loss of faith in economic individualism, may be a real advance in efforts to cope with the farm problem, the provisions in question hardly provide even the machinery for a permanent solution of that problem.

In the first place, the marketing schemes set up and administered under the statute, like all such efforts at co-operation among competitors, establish a mechanism of monopolistic control over the distribution of necessities, and endow it with power. While restrictive activities of shippers and producers within the marketing programs are subject to supervision by the government, the administration has thus far been chiefly concerned with raising farm prices, and has placed little emphasis on protection of the unrepresented consuming public. In its effort to raise prices, the government seems to have confused price rises effected by monopolization, which reduce output, with price rises responsive to greater income, which increase it. Manifestly, cartellization of this type is no substitute for economic policy; its effect is merely to permit one group to profit at the expense of the economic welfare of the community. ${ }^{53}$ Furthermore, even if the government does preserve some sort of balance between farming and consumer interests, marketing control will not aid in solving the fundamental problem of the uneconomic application of land. Although a decrease in production does result from marketing limitation, the reduction may come from a decreased output from each productive unit rather than from the elimination of sub-marginal farms. ${ }^{54}$ Finally, if marketing control is successful in raising agricultural prices by reducing output, the farm products affected may be at a corresponding disadvantage in the world market. Either all hopes of retaining or increasing farm exports must be dismissed, or resort had to some form of subsidy. ${ }^{55}$

The modest value of the marketing provisions as a factor in long-range planning therefore seems to lie in the legal machinery they afford for achieving an orderly marketing system-a necessity in any permanent scheme, for the relief of agriculture.

53. A clear exposition in a popular style of the faults of rationalization may be found in Fetter, The Masquerade of Monopoly (1931); Pigou, Economics in Practice (1935) c. vi. See also Chamberlin, The Theory of Monopolistic Cospetition (Harvard Economic Studies, 1933); Liefmann, Cartels, Concerns, and Trusts (1932) 51 et seq.; Robbins, The Great Depression (1935) c. vii; Watkins, Book Review (1936) 44 J. PoL. Ecos. 563.

54. See Hearings before Committce on Agriculture on H. R. 5585, 74th Cong., 1st Sess. (1935) passim.

55. See Schultz, Vanishisg Farm Mlarkets and Our World Trade (World Peace Foundation, 1935); Taylor, The New Deal and Foreign Trade (1935). 